\title{
Comparison on Efficiency of Foreign and Domestic Banks Evidence from Algeria
}

\author{
Ishaq Hacini ${ }^{1}$ \\ Department of Economics, University of Mascara, Algeria \\ Email:i.hacini@univ-mascara.dz \\ Khadra Dahou \\ Department of Management, University of Mascara, Algeria \\ Email: dahou.khadra@yahoo.fr
}

\begin{abstract}
The study investigates the differences in technical, pure technical, and scale efficiencies of domestic and foreign banks in Algeria over the period of 2000-2012. The study uses annual data of 10 foreign banks and 05 domestic banks operated in Algeria. The input-oriented Data Envelopment Analysis model is used to measure the banks' efficiency score. In addition, a set of parametric and non-parametric tests are used for investigating the differences in efficiency between foreign and domestic banks. The findings reveal that the banks in Algeria could improve their technical efficiency by $23 \%$. In addition, it seems that banks in Algeria suffer from the scale inefficiency. On the other hand, the foreign banks are more technically efficient than domestic banks. The superiority of foreign banks in technical efficiency is due to their superiority in the scale efficiency.
\end{abstract}

JEL classification: C14, G21, G28

Key words: Algeria, Data Envelopment Analysis, Efficiency, Domestic banks, Foreign banks

\section{INTRODUCTION}

The last two decades, the financial systems in numerous countries have witnessed radical changes. Thus, the financial industry has become more globalized, which fosters the competitions in this industry. In light of these changes, banking sectors in the developing countries, as the case of Algeria, have witnessed a series of reforms in order to enhance the banks' performance. For this purpose, the governments have endeavored to liberalize the banking sector by reducing the control and intervention of the state, remove the interest rate ceilings, reduce restrictions on the entry of foreign banks, and privatize the state-owned banks.

From an economic viewpoint, there is a strong relationship between the banks' performance and the economic development. Herring and Santomero (2000) suggested that the well

Corresponding author. Department of Economics, Faculty of Economics and Management, University of Mascara, Sidi Said, Mascara, 29000, Algeria / Email: i.hacini@univ-mascara.dz /Tel: 00213554517809. 
functioning banking sector contributes to the economic development through its role in facilitating transactions, mobilizing savings and allocating funds for the economic agents across time and space. However, the majority of studies have focused on the resource mobilization, resource allocation and enhancing the economic development as the main functions of any banking sector.

The bank's performance analysis helps to understand the process of the banking production and determining the best and worst performers. However, in the literature, the researchers have used the efficiency as a performance indicator, because the efficiency is a simple and clear concept. Thus, the efficiency examines the banks' ability to maximize their outputs without additional inputs or minimizing their inputs without reducing their inputs. Moreover, most studies have focused on the efficiency concept instead effectiveness concept as a performance indicator because in practice the effectiveness evaluation is more difficult regarding lack of information and methods to determine the firm's objectives. It is worthy to note that an efficient firm is not necessarily effective firm, the efficiency is a necessary condition for effectiveness, but it is not a sufficient condition (Mouzas, 2006).

The efficiency analysis determines why and how improving the bank performance, either by controlling inputs by improving cost efficiency using better information technology and managerial practices, or by improving outputs by improving profit efficiency through marketing and pricing strategies. On the other hand, efficiency helps managers compare the performance of their banks with the competitors through the benchmarking analysis.

Many studies have tried evaluating the entry of the foreign banks by highlighting the effect of the foreign banks' existence on the banking sector performance and comparing the efficiency of the foreign and domestic banks. Therefore, some studies such as (Karas, Schoors, and Weill, 2010; Kobeissi and Sun, 2010; Krafta, Hoflerb, and Paynec, 2006) found a strong relationship between the bank ownership and efficiency; moreover, they suggested that the foreign banks outperform the domestic bank in terms of efficiency.

The banking sector in Algeria has witnessed many reforms over the last two decades in order to improve its performance. The reforms' purpose was liberating the banks' activities and opening the banking sector to the foreign investment. As a result, the number of the foreign banks operating in Algeria reached 13 banks in, 2013. The purpose of this study is examining the efficiency of the banks in Algeria after the reforms and making a comparison between the foreign and domestic banks in terms of efficiency during the period of 2000-2012.

\section{REFORMS IN ALGERIA'S BANKING SYSTEM}

The banking system in Algeria has passed through many stages since the independence 1962 . After that, the Algerian government has planned to establish an Algerian banking system to finance the development programs with different aspects (economic, social..etc). For this end, new state-owned banks were created; in addition, the Algerian government has nationalized the foreign banks operating in Algeria since the colonial period. During the period of 1962-1985, the banking sector was completely controlled by the state. BenBitour (1998) suggested that the treasury of the state was the principal institution in the Algerian financial system; it managed the financial resources of the country, while the banks were just a channel that distributes these resources according to the government policies.

In 1986, the Algerian economy has witnessed a severe crisis caused by a drastic fall in the oil prices, which led to the contraction of the exportation revenue and curbed the economic growth. In light of this fact, it was necessary adopting a set of reforms that reformulate the Algerian economy and mainly the banking sector. Therefore, the Law on Money and Credit (LMC) ${ }^{2}$ was

Law of money and credit, № 90-10, April 1990, The Official Journal. 
issued in 1990, in which it aimed to construct a modern banking system that it is able to meet the requirements of the market economy. The main objectives of this law were moving from the directed credit banks to market-determined credit banks and enhancing the modernization and competitions in the banking sector. Thus, the Algerian authorities have started withdrawing gradually the treasury for financing the state-owned enterprises and transferred this role to the banks. Moreover, the role of the central bank in financing the deficit of the treasury has been reduced by determining a specific ceiling in financing the deficit.

For the first time, the law allowed opening the banking sector to the private investment to increase the competition level in the banking sector and improving the banks' performance. For this purpose, the authorities have removed the entry constraints in order to encourage the foreign banks to operate in the Algerian markets. On the other hand, authorities have offered the privatization of some state-owned banks by selling them to the foreign investors. As a result, the first private bank (Baraka Bank) has been established in 1990, which is a joint venture between banks from Algeria and Saudi Arabia. After that, the entry of the foreign banks has intensified since 1997. Thus, several international banks have started operating in Algeria such as; B.N.P Paribas Bank, Société Générale, Natixis Bank, Arab Banking Corporation... etc... The process of opening the banking sector to the private and foreign investment has continued with an increased pace, where in 2001, the Algerian banking system is composed of more than twenty banks and financial institutions vary between public, private, and foreign. Unfortunately, no public bank has been privatized regarding the unserious offers and the effects of the international financial crisis, in addition to the heavy bureaucratic system of the evaluation procedures in Algeria. However, foreign banks as Société Générale, B.N.P Paribas, and H.S.B.C banks have chosen to enter the Algerian market by establishing new banks instead to buy Algerian banks.

As a result of the reforms, Algeria had six public commercial banks (state-owned) and thirteen foreign commercial banks in 2013. Hence, the public banks hold $86 \%$ of the total assets of the banking sector in Algeria with 1091 branches, while the foreign banks had only 304 branches (CBA, 2013). However; the largest part of the deposits is collected by the public banks, where in 2012 the public banks collected $87.1 \%$ of the total deposits. On the other hand, the public banks dominate the credit market in Algeria, where in $201287 \%$ of loans granted to the economy are provided by the public banks, and this is due to the dominance of the public banks on the exclusivity for financing the public enterprises. In addition, the volume of the non-performing loans at the public banks is very high, especially in 2007, which reached the maximum with 680 billion DZD. In contrary, the non-performing loans of the foreign banks remain low, where, it didn't exceed 30 billion DZD (CBA, 2013).

\section{LITERATURE REVIEW}

Several studies have addressed the subject of the efficiency comparison between domestic and foreign banks. The studies have been conducted in different countries and applied several methods. However, the studies didn't find decisive results; while many studies have confirmed the proposition of foreign banks are more efficient than domestic banks, others found that domestic banks (publics) outperformed the foreign banks. Recently, Kamarudina, Sufian, Loong, and Aina, (2017) have assessed the efficiency of 23 domestic Islamic banks and 6 foreign Islamic banks in selected Southeast Asian countries over the period of 2006-2014. Data Envelopment Analysis (DEA) was used to measure the efficiency and t-Test, Mann-Whitney [Wilcoxon], and Kruskal-Wallis to test the difference in efficiency between foreign and domestic banks. The results indicated that foreign Islamic banks displayed technical efficiency equals 0.71 . In addition, domestic Islamic banks exhibited higher technical, pure and scale efficiencies than foreign banks in Malaysia, Indonesia, and Brunei. 
Wong and Deng, (2016) examined the efficiency of 39 banks in ASEAN countries during the period of 2000-2012. The study used DEA under the intermediation approach. The study found that the technical efficiency of the government banks is higher than the non-government banks. In terms of scale efficiency government and non-government banks behaved in a similar manner. In addition, government banks are higher than non-government banks in terms of cost and allocative efficiencies. Sufian and Habibullah (2012) have examined the technical, pure technical and scale efficiencies of the banking sector in Malaysia during the Asian financial crisis of 1997. The efficiency scores were estimated using DEA model, and it assumed that the bank is an intermediary between the savers and borrowers. The findings indicated that during the period of the study, the foreign banks have achieved high efficiency comparing to the domestic banks. Further analysis revealed that the scale inefficiency is the source of banks technical inefficiency rather than the pure technical inefficiency. The foreign banks tend to display high pure technical efficiency regarding their abilities to control their costs.

Karas, Schoors, and Weill, (2010) attempted comparing the efficiency of foreign and public banks in Russia in 2002 and 2006. The study used two stage DEA analysis, where in the first stage, the banks' efficiency scores were measured, and in the second stage, the mean of efficiency is regressed on a set of determinants (public ownership, foreign ownership, activity) using Tobit regression. The results indicated that foreign banks are more efficient than domestic private banks and domestic private banks are not more efficient than public banks. Cook, Hababou and Liang (2005) have examined the effect of the financial liberalization on the efficiency of the Tunisian banking system. The study was based on data from ten individual banks (five public and five private) from 1992 to 1997 . The banks' efficiency has assessed using DEA model. The study findings indicated that the technical efficiency score varied between the different banks' types, where, public banks have achieved (45.5\%), private banks (64.1\%), foreign banks $(59.1 \%)$ and local banks (43.9\%). In addition, private banks have outperformed the public banks, in which the public banks display greater inefficiency in both interest and non-interest expenses compared to the private banks. They have suggested that the financial reforms led to improving the performance of banks with different effects on various banks categories. However, the reforms have failed in closing the efficiency gap between public, domestically owned private, foreign owned banks.

This study contributes to the literature by comparing the foreign banks and domestic banks in Algeria in term of technical efficiency, pure technical efficiency, and scale efficiency. Although there have been several studies that investigate the efficiency of foreign and domestic banks in the developed countries, the empirical studies on the comparison between the efficiency of foreign and domestic banks in the North Africa countries are relatively scarce especially in Algeria. Furthermore, examining the efficiency of foreign and domestic banks in the Algerian economy, which is in transition, is important due to the crucial role of the banking system in the marketdriven economy. On the other hand, most studies those analyzed the performance of the Algerian banks focused on the domestic banks (State-Owned) due to the fact that the domestic banks dominate the Banking sector and the foreign banks are still in infancy stage because their entry in the Algerian market was in the Nineties. Therefore, the present study seeks to fill up these gaps through shedding light on the efficiency of the foreign and domestic banks.

\section{METHODOLOGY}

\subsection{Efficiency Estimation}

The Data Envelopment Analysis (DEA) is a non-parametric method for measuring the efficiency of each Decision Making Unit (DMU). The originality of DEA model is backed to (Charnes, Cooper, and Rhodes, 1978) which built a model on the efficiency's approach of (Farrel, 
1957). Farrel has attempted to develop methods for evaluating productivity for any productive organization. After that, he generalized his work to address the concept of efficiency.

DEA measures the efficiency of DMU based on its position relative to the frontier of the best DMUs performance, calculated mathematically by the ratio of the weighted sum of outputs to the weighted sum of inputs of DMUs (Thanassoulis, 2001).DEA is commonly used to evaluate the efficiency of a number of producers and each producer uses a set of inputs and produces a set of outputs. Hence, the main feature of DEA is its ability to measure the efficiency of firms with multiple inputs and outputs.

Liu, Lu, Lu and Lin (2013) have conducted a survey on DEA applications from 1978 to 2010. They found that there is a pattern of a technology-adoption process by researchers in DEA application, as they tend to adopt developed models. They revealed that DEA models have been applied mainly in banking and health care fields for the efficiency evaluation. Sherman and Gold (1985) are the first those applied the DEA in the banking field.

Charnes et al., (1978) presupposed the CCR model under the Constant Returns to Scale assumption (CRS). The CRS assumption considers that all DMUs operate at the optimal size and they are automatically scale efficient. Thus, if CRS is retained when all DMUs are not operating at optimal scale, Technical Efficiency (TE) score will be infected by scale inefficiency. The effect of the scale on efficiency score appears when a change in input levels leads to a non-equal proportionate change in output levels. Therefore, CRS assumption does not allow differentiating between the efficiency resulted from the operation's scale and the efficiency resulted from the management abilities. Thus, to overcome this shortcoming, CRS assumption should be relaxed by assessing efficiency under Variable Returns to Scale (VRS) as advocated by many studies (Afriat, 1972; Balk, 2001; Banker, Charnes, and Cooper, 1984; Fare, Grosskopf and Logan, 1983).

Banker et al. (1984) developed the BCC model that relaxed the CRS assumption by taking into account (VRS) situations. They assumed that there are $N$ DMUs $(j=1,2, \ldots, \mathrm{N})$ use $m$ inputs to produce $n$ outputs. DMUj use amount $x i j$ of input $i$ to produce amount $y r j$ of output $r$, where $x i j \geq 0, y i j \leq 0$, and each DMU has at least one positive input and one positive output value. The $\mathrm{BCC}$ is expressed as follows:

$$
\theta^{*}=\min \theta
$$

Subject to

$$
\begin{aligned}
& \sum_{j=1}^{N} x_{i j} \lambda_{j} \leq \theta x_{i o}, i=1,2, \ldots, m \\
& \sum_{j=1}^{N} y_{r j} \lambda_{j} \geq y_{r o}, r=1,2, \ldots, n \\
& \sum_{j=1}^{N} \lambda_{j}=1 \\
& \lambda_{j} \geq 0, \quad j=1,2, \ldots, N
\end{aligned}
$$

Where $\theta$ is the efficiency score and $\lambda$ is the weight of $\mathrm{DMU}_{\mathrm{j}}$. When the linear programming problem (1) is solved $\mathrm{N}$ times the efficiency score of each DMU is obtained. DMUs with $\theta<1$ are inefficient units, while DMUs with $\theta=1$ are efficient units (Farrell 1957). 
Banker et al. (1984) have differentiated between Pure Technical Efficiency (PTE) and Scale Efficiency (SE). PTE measures technical efficiency that is free from any scale efficiency. SE provides information about DMU's efficiency difference between the optimal size and the current size. SE allows determining the obtained gains from adjusting the scale size by operating at optimal size. In other words, SE expresses how close the DMU current size to the optimal size. Thus, SE is calculated indirectly by decomposing TE into two components; PTE and SE (Sufian and Abdul Majid, 2007).

\subsection{Data and Sample}

The Sample of the study includes 15 commercial banks operating in Algeria between 2000 and 2012. It consists of 10 foreign (all private) and 05 domestic (all public). The sample represents over $81 \%$ of the commercial banking assets in Algeria. The period of the study covers 12 years. In this period, the banking sector in Algeria has witnessed numerous changes among these changes the entry of the foreign banks. In addition, the most necessary data of the study are available in this period. The bank data were collected from the financial statements published by Bank-scope database. The dataset is unbalanced in the sense that the data are not all available during the period of the study.

\subsection{Input and Outputs Selection}

The selection of the banks' inputs and outputs depends on the definition of the bank and its activities, and the availability of data on the inputs and outputs. Following among others Aghimien, Kamarudin, Hamid, and Noordin (2016); Dell'Atti and Mazzarelli (2015); Johnes, Izzeldin and Pappas (2014); Yahya, Muhammad, and Abdul Hadi, (2012), this study adopts the intermediation approach. This approach considers the bank as a financial intermediary between depositors and borrowers that transforms deposits (inputs) to loans and other assets (outputs). Therefore, two inputs and three outputs are used. The inputs are $\left(\mathrm{X}_{1}\right)$ Total deposits and $\left(\mathrm{X}_{2}\right)$ Interest expenses. The outputs are (Y1) Total loans composed of loans to customers, loans and advances to banks, (Y2) Interest income, and (Y3) Non-interest income. Table (1) provides descriptive statistics of the banks' inputs and outputs during the period of the study.

Table 1

Descriptive Statistics of Inputs and Outputs (measured in millions of Algerian Dinar (DZD))

\begin{tabular}{lcccccc}
\hline \hline Type & $\begin{array}{c}\text { Descriptive } \\
\text { Statistics }\end{array}$ & \multicolumn{1}{c}{$\mathrm{X}_{1}$} & \multicolumn{1}{c}{$\mathrm{X}_{2}$} & $\mathrm{Y} 1$ & $\mathrm{Y} 2$ & $\mathrm{Y} 3$ \\
\hline & Mean & 617839.741 & 8232.878 & 497988.576 & 23259.643 & 6957.945 \\
Domestic & S.D & 531840.651 & 4669.116 & 488505.896 & 11669.202 & 7109.709 \\
Banks & Max & 2198064.10 & 21902.70 & 2069932.80 & 52787.80 & 36202.10 \\
& Min & 84451.00 & 2673.00 & 37964.00 & 2874.00 & 244.90 \\
\hline & Mean & 31263.183 & 419.838 & 31740.358 & 2268.739 & 1511.010 \\
Foreign & S.D & 36801.167 & 553.610 & 35597.947 & 2480.974 & 1760.856 \\
Banks & Max & 156429.14 & 2669.10 & 142602.28 & 9421.70 & 7499.49 \\
& Min & 453.20 & 0.01 & 214.50 & 0.01 & 0.01 \\
\hline \hline
\end{tabular}




\section{EMPIRICAL RESULTS}

\subsection{Efficiency Results}

The banks' efficiency is measured based on the inputs-orientation following the studies of Ataullah and Le (2006); Johnes et al. (2014), Yahya et al. (2012). In effect, the input-orientation efficiency model reflects the behavior of the majority of banks because they endeavor to increase their efficiency by reducing the amount of inputs used in their process. On the other hand, the banks' efficiency is measured in each year in order to capture the change of the efficiency over the period of the study. DeYoung and Hasan (1998) suggested that estimating the efficiency by constructing an annual frontier to each year is more appropriate than estimating a single multiyear frontier for the study period.

Table 2

Technical Efficiency Scores

\begin{tabular}{|c|c|c|c|c|}
\hline Year & Type & Number of Banks & Number of Efficient Banks & Mean of TE Scores \\
\hline & Domestic Banks & 5 & 0 & 0.64 \\
\hline \multirow[t]{3}{*}{2000} & Foreign Banks & 2 & 2 & 1 \\
\hline & All Banks & 7 & 2 & 0.74 \\
\hline & Domestic Banks & 5 & 2 & 0.86 \\
\hline \multirow[t]{3}{*}{2001} & Foreign Banks & 2 & 2 & 1 \\
\hline & All Banks & 7 & 4 & 0.90 \\
\hline & Domestic Banks & 5 & 0 & 0.74 \\
\hline \multirow[t]{3}{*}{2002} & Foreign Banks & 2 & 2 & 1 \\
\hline & All Banks & 7 & 2 & 0.81 \\
\hline & Domestic Banks & 4 & 0 & 0.67 \\
\hline \multirow[t]{3}{*}{2003} & Foreign Banks & 5 & 4 & 0.92 \\
\hline & All Banks & 9 & 4 & 0.81 \\
\hline & Domestic Banks & 5 & 0 & 0.72 \\
\hline \multirow[t]{3}{*}{2004} & Foreign Banks & 7 & 4 & 0.91 \\
\hline & All Banks & 12 & 4 & 0.83 \\
\hline & Domestic Banks & 5 & 0 & 0.65 \\
\hline \multirow[t]{3}{*}{2005} & Foreign Banks & 7 & 5 & 0.97 \\
\hline & All Banks & 12 & 5 & 0.84 \\
\hline & Domestic Banks & 5 & 0 & 0.56 \\
\hline \multirow[t]{2}{*}{2006} & Foreign Banks & 9 & 5 & 0.94 \\
\hline & All Banks & 14 & 5 & 0.81 \\
\hline
\end{tabular}




\begin{tabular}{|c|c|c|c|c|}
\hline Year & Type & Number of Banks & Number of Efficient Banks & Mean of TE Scores \\
\hline \multirow{3}{*}{2007} & Domestic Banks & 5 & 0 & 0.48 \\
\hline & Foreign Banks & 9 & 2 & 0.73 \\
\hline & All Banks & 14 & 2 & 0.64 \\
\hline \multirow{3}{*}{2008} & Domestic Banks & 5 & 0 & 0.38 \\
\hline & Foreign Banks & 10 & 3 & 0.73 \\
\hline & All Banks & 15 & 3 & 0.61 \\
\hline \multirow{3}{*}{2009} & Domestic Banks & 5 & 0 & 0.43 \\
\hline & Foreign Banks & 9 & 4 & 0.89 \\
\hline & All Banks & 14 & 4 & 0.72 \\
\hline \multirow{3}{*}{2010} & Domestic Banks & 5 & 1 & 0.57 \\
\hline & Foreign Banks & 10 & 3 & 0.80 \\
\hline & All Banks & 15 & 4 & 0.72 \\
\hline \multirow{3}{*}{2011} & Domestic Banks & 5 & 1 & 0.56 \\
\hline & Foreign Banks & 10 & 4 & 0.76 \\
\hline & All Banks & 15 & 5 & 0.69 \\
\hline \multirow{3}{*}{2012} & Domestic Banks & 2 & 1 & 0.70 \\
\hline & Foreign Banks & 8 & 4 & 0.84 \\
\hline & All Banks & 10 & 5 & 0.81 \\
\hline \multirow{3}{*}{$\begin{array}{l}\text { All } \\
\text { years }\end{array}$} & Domestic Banks & 61 & 5 & 0.61 \\
\hline & Foreign Banks & 90 & 44 & 0.88 \\
\hline & All Banks & 151 & 49 & 0.77 \\
\hline
\end{tabular}

Table (2) presents TE scores of the domestic and foreign banks. TE's mean of the banks as a whole ranges between 0.61 (2008) and 0.9 (2001) with an average equals 0.77 during the period of the study, suggesting that banks in Algeria have wasted 23\% of their inputs when transforming them to outputs. This means that they could use only $77 \%$ of total deposits and interest expenses to produce the same level of total loans, interest income, and non-interest income.

The comparison between the domestic and foreign banks reveals that the mean of TE of domestic banks ranges between 0.38 (2008) and 0.86 (2001) with an average equals 0.61 . While TE mean of the foreign banks ranges between 0.73 (2008) and 1 (2000) with an average equals 0.88 . Noteworthy is that among 151 bank's observations during the period of the study, foreign banks are technically efficient 44 times, while only 05 times domestic banks are technically efficient. Therefore, it is clear that the foreign banks are more technical efficiency than the domestic banks during all the period of the study. 
Table 3

Pure Technical Efficiency Scores

\begin{tabular}{|c|c|c|c|c|}
\hline Year & Type & Number of Banks & Number of Efficient Banks & Mean of PTE Scores \\
\hline & Domestic Banks & 5 & 2 & 0.78 \\
\hline \multirow[t]{3}{*}{2000} & Foreign Banks & 2 & 2 & 1 \\
\hline & All Banks & 7 & 4 & 0.84 \\
\hline & Domestic Banks & 5 & 3 & 1 \\
\hline \multirow[t]{3}{*}{2001} & Foreign Banks & 2 & 2 & 0.88 \\
\hline & All Banks & 7 & 5 & 0.91 \\
\hline & Domestic Banks & 5 & 3 & 0.92 \\
\hline \multirow[t]{3}{*}{2002} & Foreign Banks & 2 & 2 & 1 \\
\hline & All Banks & 7 & 5 & 0.94 \\
\hline & Domestic Banks & 4 & 3 & 0.95 \\
\hline \multirow[t]{3}{*}{2003} & Foreign Banks & 5 & 4 & 0.95 \\
\hline & All Banks & 9 & 7 & 0.95 \\
\hline & Domestic Banks & 5 & 4 & 0.96 \\
\hline \multirow[t]{3}{*}{2004} & Foreign Banks & 7 & 5 & 0.94 \\
\hline & All Banks & 12 & 9 & 0.95 \\
\hline & Domestic Banks & 5 & 4 & 0.98 \\
\hline \multirow[t]{3}{*}{2005} & Foreign Banks & 7 & 6 & 0.99 \\
\hline & All Banks & 12 & 10 & 0.98 \\
\hline & Domestic Banks & 5 & 3 & 0.93 \\
\hline \multirow[t]{3}{*}{2006} & Foreign Banks & 9 & 6 & 0.97 \\
\hline & All Banks & 14 & 9 & 0.96 \\
\hline & Domestic Banks & 5 & 3 & 0.94 \\
\hline \multirow[t]{3}{*}{2007} & Foreign Banks & 9 & 5 & 0.88 \\
\hline & All Banks & 14 & 8 & 0.9 \\
\hline & Domestic Banks & 5 & 4 & 0.97 \\
\hline \multirow[t]{3}{*}{2008} & Foreign Banks & 10 & 8 & 0.97 \\
\hline & All Banks & 15 & 12 & 0.97 \\
\hline & Domestic Banks & 5 & 4 & 0.96 \\
\hline \multirow[t]{3}{*}{2009} & Foreign Banks & 9 & 9 & 1 \\
\hline & All Banks & 14 & 13 & 0.98 \\
\hline & Domestic Banks & 5 & 3 & 0.94 \\
\hline \multirow[t]{2}{*}{2010} & Foreign Banks & 10 & 9 & 0.99 \\
\hline & All Banks & 15 & 12 & 0.97 \\
\hline
\end{tabular}




\begin{tabular}{|c|c|c|c|c|}
\hline Year & Type & Number of Banks & Number of Efficient Banks & Mean of PTE Scores \\
\hline \multirow{3}{*}{2011} & Domestic Banks & 5 & 5 & 1 \\
\hline & Foreign Banks & 10 & 8 & 0.97 \\
\hline & All Banks & 15 & 13 & 0.98 \\
\hline \multirow{3}{*}{2012} & Domestic Banks & 2 & 2 & 1 \\
\hline & Foreign Banks & 8 & 7 & 0.99 \\
\hline & All Banks & 10 & 9 & 0.99 \\
\hline \multirow{3}{*}{$\begin{array}{l}\text { All } \\
\text { years }\end{array}$} & Domestic Banks & 61 & 43 & 0.94 \\
\hline & Foreign Banks & 90 & 73 & 0.97 \\
\hline & All Banks & 151 & 116 & 0.94 \\
\hline
\end{tabular}

In order to identify the source of the banks' inefficiency in Algeria, TE is decomposed into PTE and SE. Table (3) reports the banks' PTE scores. The overall Banks in Algeria have displayed a high level of PTE during the period of the study. Thus, PTE's mean has been on an increasing trend, starting from 0.84 (2000) to reach 0.99 (2012) with an exception in 2007. On average, PTE's average equals 0.94 , meaning that the waste in the resources equals $6 \%$. Foreign banks have exhibited 0.97 of PTE, on average, and they were pure technically efficient 73 times from 151 bank observations, while, domestic banks have displayed 0.94 of PTE, on average, and they were 43 times pure technically efficient. Therefore, foreign banks have realized high PTE compared to domestic banks, meaning that the foreign banks utilize their inputs more efficient than the domestic banks.

Table 4

Scale Efficiency Scores

\begin{tabular}{|c|c|c|c|c|}
\hline Year & Type & Number of Banks & Number of Efficient Banks & Mean of SE Scores \\
\hline & Domestic Banks & 5 & 0 & 0.81 \\
\hline \multirow[t]{3}{*}{2000} & Foreign Banks & 2 & 2 & 1 \\
\hline & All Banks & 7 & 2 & 0.87 \\
\hline & Domestic Banks & 5 & 3 & 0.97 \\
\hline \multirow[t]{3}{*}{2001} & Foreign Banks & 2 & 2 & 1 \\
\hline & All Banks & 7 & 5 & 0.98 \\
\hline & Domestic Banks & 5 & 0 & 0.80 \\
\hline \multirow[t]{3}{*}{2002} & Foreign Banks & 2 & 2 & 1 \\
\hline & All Banks & 7 & 2 & 0.86 \\
\hline & Domestic Banks & 4 & 0 & 0.71 \\
\hline \multirow[t]{2}{*}{2003} & Foreign Banks & 5 & 4 & 0.97 \\
\hline & All Banks & 9 & 4 & 0.86 \\
\hline
\end{tabular}




\begin{tabular}{|c|c|c|c|c|}
\hline Year & Type & Number of Banks & Number of Efficient Banks & Mean of SE Scores \\
\hline \multirow{3}{*}{2004} & Domestic Banks & 5 & 0 & 0.76 \\
\hline & Foreign Banks & 7 & 5 & 0.94 \\
\hline & All Banks & 12 & 5 & 0.87 \\
\hline \multirow{3}{*}{2005} & Domestic Banks & 5 & 0 & 0.66 \\
\hline & Foreign Banks & 7 & 6 & 0.98 \\
\hline & All Banks & 12 & 6 & 0.85 \\
\hline \multirow{3}{*}{2006} & Domestic Banks & 5 & 0 & 0.61 \\
\hline & Foreign Banks & 9 & 5 & 0.97 \\
\hline & All Banks & 14 & 5 & 0.84 \\
\hline \multirow{3}{*}{2007} & Domestic Banks & 5 & 0 & 0.51 \\
\hline & Foreign Banks & 9 & 2 & 0.82 \\
\hline & All Banks & 14 & 2 & 0.71 \\
\hline \multirow{3}{*}{2008} & Domestic Banks & 5 & 0 & 0.39 \\
\hline & Foreign Banks & 10 & 3 & 0.75 \\
\hline & All Banks & 15 & 3 & 0.64 \\
\hline \multirow{3}{*}{2009} & Domestic Banks & 5 & 0 & 0.45 \\
\hline & Foreign Banks & 9 & 4 & 0.89 \\
\hline & All Banks & 14 & 4 & 0.73 \\
\hline \multirow{3}{*}{2010} & Domestic Banks & 5 & 1 & 0.6 \\
\hline & Foreign Banks & 10 & 3 & 0.80 \\
\hline & All Banks & 15 & 4 & 0.74 \\
\hline \multirow{3}{*}{2011} & Domestic Banks & 5 & 1 & 0.56 \\
\hline & Foreign Banks & 10 & 4 & 0.78 \\
\hline & All Banks & 15 & 5 & 0.71 \\
\hline \multirow{3}{*}{2012} & Domestic Banks & 2 & 1 & 0.70 \\
\hline & Foreign Banks & 8 & 4 & 0.85 \\
\hline & All Banks & 10 & 5 & 0.82 \\
\hline \multirow{3}{*}{$\begin{array}{l}\text { All } \\
\text { years }\end{array}$} & Domestic Banks & 61 & 6 & 0.65 \\
\hline & Foreign Banks & 90 & 46 & 0.90 \\
\hline & All Banks & 151 & 52 & 0.80 \\
\hline
\end{tabular}

Table (4) presents SE scores, it reveals that SE of the banks in Algeria equals 0.8, on average, and it has been on a decreasing trend starting from 2002 (0.86) reaching 0.71 in 2011. Foreign banks displayed SE score equals 0.9, on average, it ranges between 0.75 (2008) and 1 (2000), while domestic banks displayed a low level of SE equals 0.65, and ranges between 0.39 (2008) and 0.97 (2001). 
The results indicate that the banks in Algeria suffer from scale inefficiency mainly the domestic banks. This implies that banks inefficiency in Algeria is mainly attributed to the scale inefficiency rather than the pure technical inefficiency. In effect, scale inefficiency reveals that banks fail to operate at the optimal size of operations.

\subsection{Parametric and Non-parametric Tests}

The study conducts a series of parametric and non-parametric tests for examining the difference in efficiency between foreign and domestic banks. These tests are used to test the significance of the following null hypotheses:

$\mathrm{HO}_{1}$ : There is no significant difference in the TE scores between domestic and foreign banks.

$\mathrm{HO}_{2}$ : There is no significant difference in the PTE scores between domestic and foreign banks.

$\mathrm{HO}_{3}$ : There is no significant difference in the SE scores between domestic and foreign banks.

Table 5

Results of Parametric and Non-Parametric Tests (Domestic Vs Foreign Banks)

\begin{tabular}{|c|c|c|c|c|c|c|}
\hline & & \multicolumn{2}{|c|}{ Parametric Test } & \multicolumn{3}{|c|}{ Non-Parametric Test } \\
\hline & & \multicolumn{2}{|c|}{ t-Test } & \multicolumn{2}{|c|}{$\begin{array}{c}\text { Mann-Whitney } \\
\text { [Wilcoxon Rank-Sum] } \\
\text { Test }\end{array}$} & \multirow{2}{*}{$\begin{array}{c}\text { Kolmogorov- } \\
\begin{array}{c}\text { Smirnov }[\mathrm{K}-\mathrm{S}] \\
\text { Test }\end{array} \\
\text { K-S value }\end{array}$} \\
\hline & & Mean & T value & Mean Rank & $\mathrm{Z}$ value & \\
\hline \multirow{2}{*}{$\mathrm{TE}$} & Domestic Banks & 0.611 & -7.831 & 47.52 & -6.713 & 2.968 \\
\hline & Foreign Banks & 0.853 & $(0.000)$ & 95.31 & $(0.000)$ & $(0.000)$ \\
\hline \multirow{2}{*}{ PTE } & Domestic Banks & 0.938 & -2.118 & 70.19 & -1.818 & 1.010 \\
\hline & Foreign Banks & 0.972 & $(0.037)$ & 79.94 & $(0.069)$ & $(0.259)$ \\
\hline \multirow{2}{*}{$\mathrm{SE}$} & Domestic Banks & 0.655 & -7.366 & 48.98 & -6.384 & 2.968 \\
\hline & Foreign Banks & 0.875 & $(0.000)$ & 94.32 & $(0.000)$ & $(0.000)$ \\
\hline
\end{tabular}

Table (5) provides the tests' results. It is observed that for the TE null hypothesis is rejected at the 0.05 levels of significance for three tests ( $t$-Test, Mann-Whitney and Kolmogorov-Smirnov). Therefore, it implies that foreign banks are relatively more technically efficient than domestic banks $(0.85>0.61)$. Alternatively, the null hypothesis for PTE is not rejected under the NonParametric tests (Mann-Whitney and Kolmogorov-Smirnov) at the 0.05 level of significance, but this result is not confirmed by the parametric test (t-Test). Thus, it seems there is no significant difference between foreign and domestic banks, and the two types have relatively the same PTE. On the other hand, it is observed that foreign banks have exhibited a higher SE compared to domestic banks $(0.87>0.65)$ and this is statistically significant at 0.05 level for the Parametric and Non-parametric tests. These findings consist with many studies' results such as (Hasan and Marton, 2003; Karas, Schoors, and Weill, 2010; Krafta, Hoflerb, and Paynec, 2006; Nikiel and Timothy, 2002). In the literature, foreign banks in the developing countries are generally more efficient than domestic banks contrary to the developed countries the foreign banks are less efficient. 